\title{
OPTIMALISASI PERAWATAN DEEPWELL CARGO PUMPS GUNA MEMPERLANCAR KEGIATAN BONGKAR MUAT DI ATAS KAPAL MT. CORAL RIGIDA
}

\author{
Awel Suryadi $^{a}$, Darul Prayogo ${ }^{b}$ dan Ruly Samratulangic \\ ${ }^{\mathrm{a}}$ Asisten Dosen PIP Semarang \\ ${ }^{\mathrm{b}}$ Dosen Program Studi Teknika PIP Semarang \\ ${ }^{\mathrm{c}}$ Taruna Program Studi Nautika STIP Jakarta
}

\begin{abstract}
ABSTRAK
Pelabuhan merupakan tempat kapal berlabuh dan bersandar, naik atau turun penumpang dan bongkar/muat barang. Sebagai bagian dari mata rantai transportasi laut, fungsi pelabuhan adalah tempat pertemuan (interface) dua moda angkutan atau lebih serta interface berbagai kepentingan yang saling terkait. Dalam aktivitasnya pelabuhan merupakan sarana yang penting dan strategis untuk pertumbuhan perekonomian suatu negara, itu terbukti dari banyaknya kapal yang berkunjung di Pelabuhan negara tersebut.

Kegiatan bongkar muat dilaksanakan pada waktu 23.00 waktu setempat dikarenakan pihak terminal mengadakan pendinginan cargo line di darat. Dengan cargo line menanjak keatas bukit mengakibatkan rasio cargo tiap jamnya hanya sedikit. Setelah beberapa jam mengadakan kegiatan bongkar muatan, pada jam jaga Thrird Officer yang dimana cadet ikut serta dalam kegiatan jaga cargo dan Chief Officer sedang mengadakan pengecekan muatan dan pada saat itu juga deepwell cargo pumps mengeluarkan asap dan suara yang keras.

Faktor penyebab terlambatnya kegiatan bongkar muatan diatas kapal akibat kurangnya atau tidak adanya pemeliharaan dan perawatan terhadap peralatan deepwell cargo pumps. Perusahaan pelayaran harus melakukan penyeleksian terhadap pelaut yang ingin bergabung atau mengadakan pelatihan kepada pelaut sebelum mereka bergabung diatas kapal, agar sesuai dengan criteria yang diinginkan.

Mualim I di atas kapal hendaknya selalu memeriksa pekerjaan perwira lainnya agar sesuai dengan yang dikehendaki dan mendapatkan hasil yang memuaskan.
\end{abstract}

\section{Kata kunci: perawatan, deepwell cargo pumps, bongkar muat}

\section{PENDAHULUAN}

Untuk menunjang kebutuhan masyarakat di bumi akan kebutuhan gas bumi maka diperlukan pelayanan transportasi yang baik dan efisien. Jepang menjadi salah satu penghasil gas bumi yang berupa LPG (Liquid Petroleum Gas), mempunyai kerjasama dalam pengangkutan gas bumi tersebut dengan perusahaan Anthony Veder Rederijzaken B.V. yang dalam pelaksanaan operasionalnya menggunakan MT. Coral Rigida melayani dan memenuhi kebutuhan transportasi gas bumi untuk didistribusikan ke Negara lain. Kebutuhan tersebut diambil dari pelabuhan Kawasaki (JAPAN), pelabuhan Chiba (JAPAN), dan pelabuhan Oita (JAPAN).

\section{KAJIAN PUSTAKA}

Perawatan pencegahan dilakukan untuk mencegah terjadinya kerusakan atau bertambahnya kerusakan serta untuk menemukan kerusakan.

Tujuan dari pemantauan kondisi adalah untuk menemukan kembali informasi tentang kondisi dan perkembangannya, 
sehingga tindakan korektif dapat diambil sebelum terjadi kerusakan.

Deepwell pupms adalah tipe pompa yang pada umumnya digunakan di kapal gas tanker. Deepwell pumps adalah pompa sentrifugal dengan shaft yang panjang yang panjangnya diantara motor penggerak dan pompa. Shaft tersebut berada di dalam tanhki dan membongkar muatan melalui pipa dan dari lalu dipompa dibawa ke atas melewati tank dome.

\section{METODE PENELITIAN}

Metode analisa data yang penulis gunakan dalam penelitian ini adalah deskriptif kualitatif dimana data data yang diperoleh disusun secara sistematis dan teratur, kemudian penulis membuat analisa kualitatif agar diperoleh kejelasan tentang masalah yang dilakukan dalam penelitian ini. Analisa data yang dilakukan dalam penelitian ini adalah analisa terhadap perawatan deepwell cargo pumps guna memperlancar kegiatan bongkar muat. Dari penjelasan tersebut diharapkan mampu menggambarkan secara keseluruhan pokok bahasan serta pemecahan masalah penelitian ini.

\section{HASIL PENELITIAN DAN PEMBAHASAN}

Kejadian pertama pada tanggal 14 November 2008 kapal melakukan pelayaran dari Kawasaki (JAPAN) menuju Ulsan (KOREA). Memuat muatan Ethylene dengan temperatur -100 derajat celcius dan harus dibongkar di pelabuhan Ulsan (KOREA) dengan temperatur -104 derajat celcius. Tiba di pelabuhan Ulsan pada pukul 09.15 waktu setempat dan dengan bantuan Pilot kita menyandarkan kapal. Setelah sandar kapal telah siap untuk melaksanakan kegiatan bongkar muat. Kegiatan bongkar muat dilaksanakan pada waktu 23.00 waktu setempat dikarenakan pihak terminal mengadakan pendinginan cargo line di darat. Dengan cargo line menanjak ke atas bukit mengakibatkan rasio kargo tiap jamnya hanya sedikit. Setelah beberapa jam mengadakan kegiatan bongkar muatan, pada jam jaga Third Officer yang dimana cadet ikut serta dalam kegiatan jaga cargo dan Chief Officer sedang mengadakan pengecekan muatan dan pada saat itu juga deepwell cargo pumps mengeluarkan asap dan suara yang keras. $\mathrm{AB}$ jaga melaporkan langsung kejadian tersebut dan Chief Officer langsung bergegas ke deck dan langsung mematikan deepwell cargo pump nomor satu dan juga Chief Officer langsung menghubungi pihak terminal untuk memberitahu kasus tersebut. Beberapa saat kemudian pihak terminal pun datang ke atas kapal dan berdiskusi dengan Chief Officer, dengan demikian kegiatan bongkar muatan hanya dapat dilakukan dengan satu pompa dan hanya satu tangki saja yang dapat dibongkar muatannya. Setelah Chief Officer berdiskusi dengan pihak terminal untuk memperbaiki deepwell cargo pump dan kapal pun disarankan untuk melakukan labuh jangkar di luar pelabuhan untuk menghindari membengkaknya biaya pelabuhan. Setelah delapan jam melaksanakan perbaikan deepwell cargo pump dan pompa tersebut siap digunakan walaupun tidak maksimal, kapalpun siap masuk pelabuhan kembali untuk melakukan kegiatan bongkar muatan kembali. Dan kegiatan bongkar muatan dijalankan dengan tidak memakai deepwell cargo pump secara maksimal dengan waktu tiga jam bekerjanya pompa dan satu jam pompa diistirahatkan untuk menghindari keluarnya asap kembali pada deepwell cargo pump. Kegiatan bongkar muat dapat selesai dalam waktu 20 (dua puluh) jam.

Kejadian kedua pada tanggal 24 Desember 2008 kapal melakukan pelayaran dari Chiba (JAPAN) menuju Tianjin (CHINA). Di pelabuhan Chiba kapal melakukan kegiatan memuat muatan untuk dibongkar di pelabuhan Tianjin. 
Perjalanan memakan waktu lima hari untuk menuju pelabuhan tujuan, kapal tiba pada hari minggu pada pukul 10.25 waktu setempat dan langsung memakai Pilot untuk sandar di pelabuhan. Setelah kapal sandar pihak terminal langsung melakukan persiapan bongkar muatan dengan langsung menyambungkan cargo arm (lengan muatan) yang berada di darat ke atas kapal dengan dilakukan pengawasan oleh mualim jaga yang pada saat itu jam jaga mualim tiga. Kegiatan bongkar muatan yang dilakukan di pelabuhan mengalami masalah lagi pada deepwell cargo pumps, yang dimana pompa tidak dapat melakukan pembongkaran muatan. Cuaca pada saat itu musim dingin dan turun hujan salju pula. Kegiatan bongkar muatan yang pada siang hari berjalan dengan lancar dan selang waktu sepuluh jam pada waktu malam hari pompa tiba berhenti dan kapal pun mendapatkan alarm. Mualim jaga pada saat itu mualim tiga langsung melaporkan kejadian tersebut kepada Chief Officer dan Chief officer langsung bergegas ke deck dan mematikan deepwell cargo pump nomor satu. Chief officer langsung menghubungi pihak terminal untuk mengkonfirmasi kejadian tersebut. Saat itu kedua deepwell cargo pumps sedang berjalan dan dengan masalah tersebut akhirnya deepwell cargo pump hanya berjalan satu buah dan kegiatan bongkar muatan berjalan dengan rasio muatan yang kecil. Chief office dan Gas engineer dengan dibantu oleh Chief engineer memperbaiki deepwell cargo pump nomor dua agar kejadian di pelabuhan sebelumnya tidak terjadi lagi. Dalam dua jam pekerjaan dan dibantu oleh $\mathrm{AB}$ akhirnya pompa tersebut dapat berjalan kembali dan kegiatan bongkar muatan kembali lancar. Chief Officer langsung menghubungi pihak terminal dan pihak terminal langsung memberikan pemberitahuan untuk menaikkan rasio muatan dan Chief officer pun menyetujui hal tersebut dengan penggunaan pompa tidak dengan kekuatan penuh. Kegiatan bongkar muatan dapat terselesaikan dalam waktu delapan belas jam.

\section{PENUTUP}

\section{A. Kesimpulan}

1. Faktor penyebab terlambatnya kegiatan bongkar muatan di atas kapal adalah kurangnya atau tidak adanya pemeliharaan dan perawatan terhadap peralatan deepwell cargo pumps;

2. Kurangnya kedisiplinan perwira dalam melakukan perawatan sehingga perawatan menjadi terabaikan dan tidak berjalan sesuai prosedur yang ditetapkan sebagaimana mestinya;

3. Untuk memperkecil atau menekan kerusakan dan menekan biaya yang besar keluar maka kapal/perusahaan menggunakan strategi perawatan berencana.

\section{B. Saran}

1. Perusahaan pelayaran harus melakukan penyeleksian terhadap pelaut yang ingin bergabung atau mengadakan pelatihan kepada pelaut sebelum mereka bergabung di atas kapal, agar sesuai dengan kriteria yang diinginkan.

2. Mualim I di atas kapal hendaknya selalu memeriksa pekerjaan perwira lainnya agar sesuai dengan yang dikehendaki dan mendapatkan hasil yang memuaskan.

3. Engineer di atas kapal agar selalu melakukan perawatan peralatan deepwell cargo pumps untuk menunjang kegiatan bongkar muatan di atas kapal.

\section{DAFTAR PUSTAKA}

H. I. Lavery. 1999. Ship Board Operation. 2nd Edition. London: BH. Uk

IMO. 2002. International Safety Management Code. London : $\mathrm{BH}$. Uk 
Optimalisasi Perawatan Deepwell Cargo Pumps Guna Memperlancar Kegiatan Bongkar Muat Di Atas Kapal Mt. Coral Rigida

Awel Suryadi $^{a}$, Darul Prayogo ${ }^{\text {b }}$ dan Ruly Samratulangi ${ }^{\mathrm{c}}$

Lasse. 2004. Manajemen Kepelabuhanan. Jakarta: Rajawali

NSOS. Managemen Perawatan dan Perbaikan. Dirjen Hubla

Pelabuhan Tanjung Priok. 2007. Jakarta: PT. Pelindo II

Sea Gull Training. 2008. Gas Tanker Familiarisation Ang Advance

Simanjuntak, Marihot. 2001. Teknik Perbaikan Dan perawatan Kapal Program $D I V$. Jakarta : STIP Jakarta

Suyono, R. P. 2007. Shipping Pengangkutan Intermodal Ekspor Impor Melalui Laut. Jakarta: Argya Putra

Triatmodjo, Bambang. 2010. Perencanaan Pelabuhan. Jakarta: Beta

UU No. 17 Tahun 2008 Tentang Pelayaran 